\title{
ДО ПИТАННЯ ЕМОЦЙНОЇ ВИКОНАВСЬКОЇ СТАБІЛЬНОСТІ ФАХІВЦІВ МУЗИЧНОГО МИСТЕЦТВА
}

\section{Ян Цзяін}

здобувач третього (освітньо-наукового) рівня вищої освіти кафедри освітології та інноваційної педагогіки, Харківський національний педагогічний університет імені Г.С. Сковороди, м. Харків, Україна

У статті висвітлено питання емоційної стабільності. Розкрито підходи психологів до визначення ичієї дефініції, показано внутрішні (особистісні) і зовнішні (міжособистісна, соціальна підтримка) ресурси, щуо ї̈ підтримують. Надано характеристику емоційної виконавської стабільності фахівців музичного мистецттва для їх успішної виконавської діяльності.

Ключові слова: емочійна виконавська стабільність, фахівці музичного мистеитвв.

The article highlights the issues of emotional stability. The approaches of psychologists to the definition of this definition are revealed, internal (personal) and external (interpersonal, social support) resources that support it are shown. The emotional performance stability of music specialists for their successful performance is characterized.

Key words: emotional performance stability, music experts.

Фахова діяльність майбутнього фахівця музичного мистецтва як інструменталіста, диригента та вокаліста має свою специфіку. Різні види публічного виступу (заліки, іспити, концерти, конкурси), потребують значних емоційних та фізичних напружень. Кожен прилюдний вихід завжди викликає хвилювання, що може погіршити результат публічного виступу або навпаки, стимулювати творчий потенціал виконавця та бути кращим, ніж у процесі підготовки.

Для визначення шляхів інтенсифікації підготовки майбутніх фахівців музичного мистецтва до емоційної виконавської стабільності 3'ясуємо сутність цього поняття.

Поняття «стабільність» (stability — в перекладі з англ. означає стабільність, стійкість, відповідна постійність) [2, с. 314].

У психології існують різні підходи до трактування психологічної стабільності. Для психологічної стабільності особистості важливою $€$ здатність до саморозвитку, до формування власної індивідуальності. Стабільність, є сукупністю адаптаційних процесів, інтегрованість осо- 
бистості у плані збереження узгодженості основних функцій, стабільності їх виконання.

За визначенням В. М. Крайнюк, «психологічна стабільність, — це складна якість особистості, в якій об'єднані: врівноваженість (рівновага), відповідність; стійкість, стабільність (постійність); опірність (резистентність)» [3, с. 143]. Врівноваженість - це здатність утримувати рівень напруження, не виходячи за межі прийнятного (не доводячи до руйнівного стресу). Під «стійкістю» розуміється здатність протистояти труднощам, зберігати віру в ситуаціях фрустрації, а під «стабільністю» - постійний рівень настрою. Опірність - це здатність зберігати свободу поведінки і вибору способу життя, це самодостатність як свобода від залежності (хімічної, інтеракційної або поведінкової).

Психологічну стабільність підтримують внутрішні (особистісні) і зовнішні (міжособистісна, соціальна підтримка) ресурси. До них відносяться:

- фактори соціального середовища, що підтримують самооцінку; сприяють самореалізації; підтримують адаптивні потенціали й енергетичні ресурси організму; психологічна підтримка соціального оточення (емоційна підтримка близьких, друзів, їхня конкретна допомога у справах тощо);

- особистісні фактори, свідомість — віра в різних проявах; розуміння, відчуття сенсу життя, осмисленість діяльності й поведінки; установка на те, що можеш розпоряджатися своїм життям; усвідомлення соціальної приналежності до певної групи; ставлення (у тому числі й до себе): оптимістичне, активне до життєвої ситуації; філософське відношення до важких ситуацій; погодженість Я-сприйманого і Я-бажаного; достатньо висока самооцінка; упевненість, незалежність у відносинах з іншими людьми, відсутність ворожості, довіра;

- когнітивна сфера - розуміння життєвої ситуації й можливість iii прогнозування; раціональні судження; адекватна оцінка величини навантаження і своїх ресурсів; структурований досвід подолання важких ситуацій;

- емоційна сфера - домінування стенічних позитивних емоцій; переживання успішності самореалізації; бажане емоційне насичення від міжособистісної взаємодії, переживання почуття згуртованості, єдності; 
- поведінкова (і діяльнісна) сфера - поведінкова активність; ефективна вольова регуляція; використання ефективних засобів подолання труднощів;

- комунікативна сфера - відкрите спілкування, прийняття інших такими, які вони є (терпимість); стійкі міжособистісні ролі, що задовольняють індивіда; задовольняючий статус у групі й соціумі; виражене почуття спільності.

У цьому списку перераховані позитивні полюси якостей і факторів. При сприятливому впливі факторів домінуючий психічний стан резистентний, а домінуючий настрій — гармонійний (стійкий, підвищений, оптимістичний). При несприятливому впливі домінуючий стан стає дезадаптаційним, стресовим або депресивним (апатія, зневіра, тривога тощо) і дисгармонійний настрій (нестійкий, знижений, тривожний).

3 поняттям «психологічної стабільності» повязане поняття «емоційна стабільність». Головними складовими, «фундаментальними компонентами» емоційної стабільності, у визначенні В. Мільмана, $\epsilon$ адекватність емоційної оцінки ситуації, відповідність емоційних реакцій [4, с. 149]; у визначенні О. Варданяна - гармонійність відносин між усіма компонентами діяльності в емоціогенних умовах.

Л. Аболін дає наступну характеристику емоційної стабільності це властивість, що характеризує індивіда у процесі напруженої діяльності, окремі емоційні механізми якої, гармонійно взаємодіючи між собою, сприяють успішному досягненню поставленої мети. Інтегративним критерієм емоційної стабільності є результат, що характеризує, наскільки успішно чи неуспішно досягається поставлена людиною мета $[1$, с. 98].

Отже, поняття «емоційної стабільності» слід розглядати як стійкість до продуктивної діяльності, що здійснюється в напружених умовах.

Для визначення емоційної виконавської стабільності майбутніх фахівців музичного мистецтва необхідно виявити особливості їхньої виконавської діяльності якими є: специфіка виконавства у конкретних видах музичного мистецтва (інструментальне, вокальне, диригентське); спрямованість на слухацькі аудиторії різних рівнів.

Виконавська діяльність майбутніх фахівців музичного мистецтва $\epsilon$ багатоаспектною, специфічною та різновекторно спрямованою про- 
фесійною діяльністю, яка має різну напругу. Сукупність фахових знань, умінь, навичок, компетентностей, професійно-особистісних якостей і здібностей, практичного досвіду і норм поведінки має забезпечувати успішних публічних виступів.

Фахівець музичного мистецтва в школі - це вокаліст, інструменталіст, концертмейстер, диригент, теоретик тощо. Тому його професійна підготовка залежить від цілісної музично-педагогічної освіти, що розглядається як єдиний процес музично-виконавських, музично-теоретичних, психолого-педагогічних знань, умінь та навичок. Для успішної підготовки фахівців цієї галузі необхідно готувати висококваліфікованого не тільки педагога, а й досвідченого виконавця. Проте не завжди студент, майбутній учитель музичного мистецтва, готовий психологічно до виконавської діяльності. В умовах емоціогенного стресу, у незвичних психологічних ситуаціях, під час концертних виступів студент може розгубитись і не показати в своєму публічному виконанні всього того, що було досягнуто в процесі підготовки. Тому вкрай необхідно навчити студента сконцентруватися, проявити певні професійно-особистісні якості (емоційну стійкість, впевненість в собі тощо) і показати високий рівень виконання.

У цьому аспекті викладачі вищої школи з мистецьких дисциплін повинні формувати в студентів певні властивості, здатності до успішної публічної виконавської діяльності, яку ми розуміємо як емоційну виконавську стабільність.

\section{Список використаних джерел:}

1. Аболин Л. М. Психологические механизмы эмоциональной устойчивости человека / под ред. В. В. Давыдова. Казань, 1987. 262 с.

2. Веракіс А. І., Левківський Ю. І. Основи психології : навч. посіб. Київ : Харків, 2005. 416 c.

3. Крайнюк В. М. Порівняльний аналіз індивідуально-психологічних властивостей стресостабільності рятувальників у посттравматичний період. Наука освіта: наук.-практ. журн. Півден. наук. центру АПН України. Спецвипуск: Психологія особистості, досвід минулого - погляд у майбутн. 2004. С.142-146.

4. Мильман В. Э. Мотивация творчества и роста: Структура. Диагностика. Развитие Москва : Мирея и ко, 2005, 166 с. 